EESTI NSV TEADUSTE AKADEEMIA TOIMETISED 1953. II k., nr. 1

ИЗВЕСТИЯ АКАДЕМИИ НАУК ЭСТОНСКОИ ССР 1953. Том II, А

\title{
LUTSERNI KASVATAMINE EESTI NSV-S
}

\section{R. TOOMRE,}

põllumajandusteaduste kandidaat

Partei XIX kongressi direktiivides NSV Liidu arendamise viienda viie aasta plaani kohta märgitakse pöllumajanduse alal ühe peaülesandena kõigi pōllumajanduslike kultuuride viljakuse tōstmist. Pōllumajanduslike ku'tuuride viljakuse pideva tōstmise aluseks on aga maaviljeluse heinaväljasüsteemi sisseviimine. Akadeemik V. R. Viljamsi poolt välja töötatud agronoomilisele mullateooriale tuginev maviljeluse heinaväljasüsteem ühendab ühtseks süsteemiks need agronoomilised abinõud, mis antud konkreetsetes tingimustes kindlustavad põllumajanduslike kultuuride saakide pideva tõstmise. Akadeemik T. D. Lõssenko oma artiklis maaviljeluse heinaväljasüsteemi rakendamisest, mis ilmus „Pravdas" 1950 . a. $\left({ }^{4}\right)$, märgib, et selles süsteemis kui agronoomiliste abinõude skeemis peavad kajastuma erinevatest kohalikest looduslikest tingimustest tulenevad erinevused. Maaviljeluse heinaväljasüsteemi sisseviimisel tu'eb esmajärjekorras arvestada antud territooriumi mullastikku. Eesti NSV mullastik on väga mitmekesine ja sellest mitmekesisusest tingituna kerkib esile rida asjaolusid, mida tu'eb maaviljeluse heinaväljasüsteemi rakendamisel arvestada. Kuigi valitsevaks mullatüübiks vabariigis on leetmullad, on suur osatähtsus ka karbonaatsetel muldadel. Viimased moodustavad kogu vabariigi territooriumist ligikaudu ühe kolmandiku.

Karbonaatsete muldade valdkonnas tekib raskusi heinavälja-külvikordade rakendamisel ôhukestel tüüpilistel karbonaatsetel muldadel. Nendel muldadel tavaliselt ei ōnnestu ristiku-kōrreliste segude kasvatamine. Sellega seoses on takistatud ka heinavälja-külvikordade rakendamine, sest puuduvad vajalikud eeldused heinavälja-külvikorra pōhimise lüli, ristikukōrreliste segude kasvatamiseks ja nende kõrgete saakide kindlustamiseks.

Ohukestest tüüpilistest karbonaatsetest muldadest on pōllumajanduse seisukohalt olulisema tähtsusega ōhukesed, savikal rähal asuvad karbonaatsed mullad (ōhukesed rähkmullad). Ohukesele $\left(A_{1}+B-20-50 \mathrm{~cm}\right.$ piirides) mullakihile järgneb siin savikas karbonaatne rähk. A. L i 11 e m a $\left({ }^{3}\right)$ järgi sisaldavad need mullad keskmiselt $3-4 \%$ huumust, $0,20-0,25 \%$ lämmastikku ja nende $\mathrm{pH}$ kõigub 6,5-7,5 piirides. Künnikiht on üldiselt ōhuke. Mullad on pöuakartlikud, sest pealmiste kihtide $\left(A_{1}+B\right)$ niiskusevarud on väga piiratud. Künnikihi süvendamine on siin savika räha tõttu raskesti teostatav. Pöllukultuuride, nende hulgas ka pôldheina (ristikukõrreliste segud) saagid on õhukestel karbonaatsetel muldadel madalad. Väetiste kasutamine on väheefektiivne, sest ka normaalsete sademetega aastatel jääb niiskusevaru enamiku põllukultuuride juurtele kättesaadavas 
sügavuses piiratuks. Ohe- ja kaheaastaste pōllukultuuride kasvatamist raskendab ka asjaolu, et mullaharimistööde teostamine on siin raskendatud mullaharimisriistade äärmiselt suure kuluvuse ja räha lähedusest tingitud alaliste avariide tõttu.

Kuigi ōhukeste karbonaatsete rähkmuldade osatähtsus ei ole eriti suur, moodustades vabariigi territooriumist ligikaudu $8 \%$, tõuseb see kohati küllalt kōrgele. Nii näiteks moodustavad öhukesed karbonaatsed rähkmullad üksikutes rajoonides praegusest pōllumaa kogupindalast kuni $50 \%$.

Seoses maaviljeluse heinaväljasüsteemi sisseviimisega toimub ka pōllumajanduslike kölvikute ulatuslik ümberkorraldamine, kusjuures ōhukeste karbonaatsete muldade osatähtsus pōllumaa üldpinna suhtes otsustavalt väheneb. Sellega ei lange siiski veel ära ōhukeste karbonaatsete muldade otstarbekohase ja ratsionaalse kasutamise küsimus. Vastupidi, maaviljeluse heinaväljasüsteemi sisseviimise käigus tuleb leida nende muldade ōige kasutamisviis. Et ōhukesed karbonaatsed mullad on üldiselt toitaineterikkad, niiskusevarud mulla ülemistes kihtides aga ei võimalda enamikule pōllukultuuridele, esijoones aga pōldheinale (ristiku-kōrreliste segud), normaalseid arenemistingimusi, siis tuleb siin kasvatada selliseid kultuure, mis on võimelised rahuldama oma peamise veetarbe sügavamate kihtide niiskusevarude arvel. Selliseks kultuuriks osutub lutsern. Lutserni juured tungivad kuni kümne meetri sügavusse $\left({ }^{5,7}\right)$, kusjuures lutsern on vöimeline andma saaki pikema aja kestel. Need kaks omadust on väga olulised ōhukeste karbonaatsete rähkmuldade kasutamisel lutserni kasvatamiseks, sest nad aitavad üle saada kahest pōhimisest raskusest selle mullatüübi põllumajanduslikul kasutamisel, nimelt alalise niiskusepuuduse pidurdavast mōjust taimekasvule ja raskustest mullaharimistöödel, sest pikema kasutusaja tōttu mullaharimistööd üldiselt vähenevad. Seepärast ei tule lutserni kasvatamisele Eesti NSV-s vaadata ainult kui uue heinakultuuri kasutuselevōtmisele lisaks senistele, vaid kui ōhukeste karbonaatsete muldade viljakuse tōstmise pōhiküsimusele. Et lutserni saak karbonaatsetel muldadel tavaliselt ületab ristiku saagi, lutserni söödaväärtus aga on ristiku omast kõrgem, siis kujuneb ta karbonaatsetel muldadel otsustava tähtsusega heinakultuuriks. Lutserni kasvatamise laiendamine karbonaatsetel muldadel aitab paremini ära kasutada nende muldade viljakuse reserve ja tunduvalt suurendada taimekasvatuse toodangut. Lutserni kasvatamise küsimus muutub seega maaviljeluse heinaväljasüsteemi rakendamise küsimuseks karbonaatsete muldade valdkonnas.

Maaviljeluse heinaväljasüsteemi sisseviimisel tekib raskusi ka OtepääHaanja kuppelmaastikul asuvates kolhoosides. Põllumajanduslik maa koosneb siin kuplite nōlvakutest ja kupleid eraldavatest soostunud nõgudest. Pōllumaad asuvad peamiselt kuplitel, kusjuures kōlvikute kaldad sageli ületavad $10^{\circ}$. Põllumassiivid koosnevad mônehektaristest lahustükkidest. Uhtsete massiivide moodustamine on reljeefi tõttu raske. Pöllumaadel esinevad tugevad erosiooninähted. Mullaharimistööde ulatuslikumat mehhaniseerimist takistab haritavate alade väike pindala ja nōlvakute suur kalle. Mullastik on siin väga kirju. Olenevalt mulla vahelduvast lähtematerjalist, esinevad nii leet- kui ka karbonaatsed mullad. Maaviljeluse heinaväljasüsteemi rakendamisel tuleb tunduvat osa suurema kallakuga kupleid paratamatult kasutada pikema kestvusega heinakultuuride kasvatamiseks, sest vastasel korral ei saa siin pidurdada erosiooni. Arvestades mullastikutingimusi, on ka siin eeldusi lutserni kasvatamiseks.

Lutserni ulatuslikum kasvatamine võimaldab neil järskudel nõlvakutel pikema aja kestel toota kōrgeväärtuslikku loomasööta. Rööbiti sellega aga väheneb vahelduval relieefil üldine mullaharimistööde maht, mis antud tingimustes on väga oluline. 
Eesti NSV oludes ei ole lutsern uueks kuituuriks. Teda on piiratud ulatuses kasvatatud juba aastakümneid. Vaatamata sellele laienes lutserni kasvupindala äärmiseit aeglaselt. 1951. aastal moodustas lutserni kasvupindala vabariigis ainult ligikaudu $0,2 \%$ pöldheina kogu kasvupinda'ast, kusjuures $77 \%$ lutserni kasvupindalast asus karbonaatsete muidade valdkonnas. Lutserni kasvatamise äärmise't aeg'ast levikut se'etati meil peamiselt seemne saamise a'al esinevate raskustega. Tegeliku't aga ei näi pōhjused peituvat mitte ainult seemneküsimuses. Lutserni kasutati väikemajapidamiste tingimustes peamiselt ristikute asendajana pōldheinasegudes. Järelikult vaadati lutsernile kui täiendava'e komponendile põ'dheinasegus, millega oleks soodsal vôima'usel saanud asendada ristikut. Et aga lutserni seemnekasvatus oli seotud suuremate raskustega, siis näis puuduvat perspektiiv ristiku asendamiseks lutserniga pōldheinasegudes. Lutserni kasvatamise küsimust kui teatud mullatüüpide parema ärakasutamise vöimalust ulatuslikumalt üles ei tõstetud. Lutserni kasvatamise küsimuse selline kitsas käsitlus oli suurel määral tingitud väikemajapidamiste piiratud. tingimustest.

Olukord muutus täielikult seoses kolhooside tekkimisega. Maavilje'use heinaväljasüsteemi kui sotsialistlikule pôl'umajanduse'e omase maakasutussüsteemi sisseviimisele asudes kerkis teravalt päevakorda sel'iste mullatüüpide otstarbekohane kasutamine, kus pō:dhein (ristiku-kōrreliste segud) ja rida teisi pōllukultuure ei suuda mulla niiskusevarude piiratuse tōttu pidevalt kindlustada rahuldavaid saake. Senistest kogemustest aga nähtus, et lutsern vōib neis tingimustes kasvada enam-vähem normaalselt. Sellega kerkis üles konkreetne vajadus lutserni kasvatamise laiendamiseks.

Eeltoodut iseloomustavad andmed lutserni kasvatamisest Orissaare rajoonis. Rajooni peaagronoomi A. A b e ( $\left.{ }^{1}\right)$ andmetel suurenes rajooni territooriumil lutserni kasvupindala kuni 1948. aastani väga aeglaselt. Viimase 16 aasta jooksul oli lutserni kasvupindała rajooni territooriumil tōusnud ainult 40 hektarile. 1951. aastaks tōusis lutserni kasvupinda!a aga 182 hektari!e, seega oli ta kolme aasta jooksul suurenenud rohkem kui 4 korda. Seejuures toimus kasvupinna suurendamine kohapeal kasvatatud lutserniseemne arvel. 1952. a. sügisel ületas lutserni kasvupindala rajoonis 1948. a. oma rohkem kui 12 korda.

Lutserni kasvatamisega seoses oleva uurimisega on vabariigis pikemat aega tegelnud Eesti Põllumajanduse Akadeemia taimekasvatuse kateeder, Jögeva Riiklik Sordiaretusjaam ja Eesti NSV Teaduste Akadeemia Taimekasvatuse Instituut. Käesolevas töös käsit'letakse peamiselt Taimekasvatuse Instituudi poolt teostatud uurimisi, sest need haaravad esijoones lutserni kasvatamise küsimusi ōhukestel karbonaatsetel mu!dadel.

Taimekasvatuse Instituudi Kuusiku filiaalis alati lutserni kasvatamise katsetega ōhukestel ja keskmise sügavusega karbonaatsetel mu!dadel 1945. aastal. Katsetes püüti esmajärjekorras selgitada, missugusel määral saab Iōunapoolse päritoluga lutsernisorte kasutada lutserni kasvatamise laiendamiseks Pōhja-Eesti tingimustes. Samaaegse't pöörati tähe'epanu ka seemnekasvatuse võimaluste selgitamise'e. Alates 1949. aastast laiendati katseid nii Kuusiku filiaalis kui ka sama instituudi Orissaare rajoonis asuvas Karja-Pärsamaa katsemajandis.

Jōgeva Riiklik Sordiaretusjaam tegeleb juba pikemat aega lutserni sordiaretusega. Siin on välja aretatud kohalikke lutsernisorte, mis katsetes on silma paistnud löunapoolse päritoluga sortidega võrre'des kōrgemate seemnesaakide poolest. Lutserni sordiaretuse küsimusega on viimastel aastatel tegelnud ka Eesti NSV Teaduste Akadeemia Maaparanduse ja Sookultuuri Instituut. Eesti Põllumajanduse Akadeemia taimekasvatuse katee. der tegeleb lutserni kasvatamise küsimustega leetmuldadel. 


\section{Lutserni kasvatamise senistest tulemustest ja saagivõimest}

Senistest uurimistu'emustest ja tootmiskogemustest selgub, et lutserni saab eduka:t kasvatada ka ōhukestel rähkmuldadel, kusjuures ta suudab anda rahu'davaid saake rea aastate kestel. Nii saadi Taimekasvatuse Instituudi Kuusiku katsemajandis õhukese'e karbonaatse'e (rähk-) mullale rajatud lutserni kasvatuskatses 4 aasta keskmisena aastas 65,8 ts kuivheina hektarilt. Samas majandis saadi 1952. aastal 6,8 ha suuruselt lutsernipöllu't (4.-6. eluaasta), mis asub ōhukesel rähkmullal, esimese lōikusena keskmise't 50,4 ts kuivheina hektarilt, kusjuures kõrgeim saak oli 104,8 ts/ha. Lutserni keskmine saak ületas põ:dheina (ristiku-timuti) keskmise saagi, mis kasvas sügavamatel ja viljakamatel muldadel, 16,3\% vōrra. Harju rajoonis A. Sommerlingi nimelises sovhoosis saadi 14-hektariselt lutsernipō'lu't ko'me kasutusaasta keskmisena aastas 61 ts kuivheina hektarilt esimese lōikusena. Lutserni keskmine saak ületas ligikaudu kahekordselt ristiku-timuti keskmise saagi ülaltähendatud majandis. Orissaare rajoonis saadakse kolhoosides üle 10 aasta vanustelt lutsernipõ'dudelt, mis on rajatud ōhukeste!e rähkmuldadele ja kus põllukultuuride saagid osutuvad äärmiselt madalateks, aastas keskmiselt $40-70$ ts kuivheina hektarilt.

Vörreldes lutserni ja ristiku saake samades kasvutingimustes, näeme, et esimene ületab viimase tunduvalt. Taimekasvatuse Instituudi Kuusiku filiaali katsetest selgub, et lutserni saak ületas kahe esimese kasutusaasta keskmisena ristiku saagi $56,2 \%$ vōrra, segus timutiga aga $40,7 \%$ vōrra. Kolmandal kasutusaastal oli ristik täielikult hävinenud, lutserni saak aga tõusis teise kasutusaasta saagiga võrreldes $20,4 \%$ võrra (tabel 1).

Tabel 1

Ristiku ja lutserni puhaskülvide ning timutisegude saagid 1946.-48. aastal õhukestel rähkmuldadel Eesti NSV TA Taimekasvatuse Instituudi Kuusiku katsemajandis

\begin{tabular}{|c|c|c|c|c|}
\hline \multirow{3}{*}{$\mathrm{K}$ iี I v } & \multicolumn{4}{|c|}{ Keskmine saak ha-lt aastas } \\
\hline & \multicolumn{2}{|c|}{$\begin{array}{c}\text { kahel esimesel kasutus- } \\
\text { aastal }\end{array}$} & \multicolumn{2}{|c|}{ kolmel esimesel kasutusaastal } \\
\hline & ts & $\%$ & ts & $\begin{array}{c}\% \text {-des vörreldes kahe } \\
\text { esimese kasutusaasta } \\
\text { saagiga }\end{array}$ \\
\hline $\begin{array}{l}\text { Punane ristik } \\
\text { Punane ristik }+ \text { timut } \\
\text { Lutsern } \\
\text { Lutsern }+ \text { timut }\end{array}$ & $\begin{array}{l}21,0 \\
26,8 \\
32,8 \\
35,3\end{array}$ & $\begin{array}{l}100,0 \\
127,6 \\
156,2 \\
168,1\end{array}$ & $\begin{array}{l}14,0 * \\
21,7 \\
39,5 \\
40,7\end{array}$ & $\begin{array}{r}66,7 \\
81,3 \\
120,4 \\
115,3\end{array}$ \\
\hline
\end{tabular}

Edasi selgub katseandmetest, et õhukestel rähkmuldadel annab lutsern esimestel eluaastatel tunduvalt madalama saagi kui hilisematel. Nii näiteks andis Taimekasvatuse Instituudi Kuusiku katsemajandis lutsern teisel ja kolmandal eluaastal 41,5 ts kuivheina hektarilt, viiendal-kuuendal eluaastal aga 87,3 ts. Viienda-kuuenda eluaasta saak oli teise-kolmanda eluaasta omaga võrreldes suurenenud rohkem kui kahekordseks. Sama nähtub ka teistes ôhukestel rähkmuldadel asuvates kasvukohtades. Nii näiteks olid Orissaare rajoonis Uhenduse kolhoosis 1951. aastal 2-3-aastaste lutsernipõldude saagid madalamad kui vanematel (üle 10 aasta vanustel) põldudel, kus-

- Kolmandaks kasutusaastaks oli punane ristik täielikult hävinenud. 
juures taimede tihedus noorematel lutsernipõldudel oli isegi suurem. Seletatav on see sellega, et esimestel eluaastatel ei suuda lutsernitaimed oma juurestikku vajalikult välja arendada sügavatesse saviräha kihtidesse, kus niiskusevarud on suuremad. Taimed kannatavad niiskuse puuduse all, juurekaelast arenevate võrsete arv jääb väheseks ja saak kujuneb esimestel eluaastatel madalamaks.

Eesti Pőllumajanduse Akadeemia taimekasvatuse kateedri* andmetest $\left({ }^{2}\right)$ selgub, et lutsern võimaldab saada kõrgeid saake ka nõrgalt leetunud muldadel. Nii saadi Eesti Põllumajanduse Akadeemia Raadi katsemajandis kolme aasta keskmisena 72,3 ts lutserni kuivheina hektarilt, samal ajal kui ristiku-timuti segu saak oli 43,0 ts/ha. Raadi katsemajandi sügavamatel, nõrgalt leetunud muldadel, kus niiskusevarud ōhukeste rähkmuldadega võrreldes on rahuldavad ka mulla ülemistes kihtides, saavutab lutsern oma täie saagivõime juba esimestel eluaastatel. Hiljem saak enam ei tôuse, vaid hakkab langema. Nii oli keskmine saak hektari kohta teisel-kolmandal eluaastal 103,8 ts, viiendal-kuuendal eluaastal 80,9 ts.

\section{Lutserni liikidest ja sortidest}

Lutserni liikidest kasvatatakse Eesti NSV-s peamiselt sinist (harilikku) lutserni (Medicago sativa L.) ja viimase hübriidvorme. Käesoleval ajal kasvatatava lutserni algseeme pärineb suuremalt osalt Tšehhoslovakkiast ja Ungarist. Sinise lutserni ja selle hübriidide kõrval kasvatatakse piiratud ulatuses sirplutserni (Medicago falcata L.). Viimastest tuleb esijoones märkida saartelt pärinevat kollast lutserni, mis on piiratud ulatuses levinud saarte rajoonides. Senistest lutserni kasvatamiskogemustest järeldub, et lutsernikasvatuse laiendamiseks saab edukalt kasutada lōunapoolse päritoluga lutserniseemet.

Lutserni sordi ja päritolu mõju saagikusele aitavad selgitada Taimekasvatuse Instituudi Kuusiku filiaali poolt korraldatud katsed. 1945. aastal rajati Kuusiku katsemajandis katsed ōhukesele rähkmullale vile lutsernisordiga: Balti 29, Moskva nr. 1, Grimm-Zaikevitš ja sirplutsernidest Dedinovi kollane (seemned saadud Oleliiduliselt Söötade Instituudilt) ning Ukraina NSV-st pärinev lutsern. Külv teostati laiarealiselt (50 $\mathrm{cm}$ reavahega), külvinormiga $10 \mathrm{~kg}$ idanevat seemet ha-le. Väetamine ja hooldamine oli kõigil katsevariantidel katseperioodi vältel ühtlane, kusjuures aastas antava fosfor- ja kaaliumväetise keskmine kogus, ümber arvestatuna toimeainele, oli $60 \mathrm{~kg} \mathrm{P}_{2} \mathrm{O}_{5}$ ja $60 \mathrm{~kg} \mathrm{~K}_{2} \mathrm{O}$. Katseandmetest selgub, et 5 aasta keskmisena andis sinistest lutsernidest kōrgeima saagi B a lt i 29, ületades teiste sortide ja päritolude keskmised saagid ligemale $20 \%$ võrra (heinasaagid katseperioodi kestel on toodud tabelis 2 ). Hiljem rajatud lutserni sordivôrdluskatsetes paistis oma kõrgema saagikusega samuti silma B alti 29. 1949/50. a. keskmisena andis ta ha-lt 73,7 ts kuivheina. Saagikuse poolest ületas teda ainult J õ g e va vär d. 1 utser $n$, mis andis samal ajal 81,3 ts/ha. Köigil sortidel oli saak esimestel eluaastatel hilisemate eluaastate saagist ligikaudu kaks korda madalam. Taimekasvatuse Instituudi Kuusiku filiaalis 1952. aastal teostatud vaatluste kohaselt ** osutusid katsetusel olnud lutsernisortidest vastupidavaimateks Balti 29 ja Dedinovi kollane. Taimede tihedus oli väiksem sordil Grimm-Z a i kevit $̌$ ja Ukraina päritoluga lutsernil.

* Kuni 1951. aastani Tartu Riikliku Olikooli taimekasvatuse kateeder.

** Vaatlusi teostas Taimekasvatuse Instituudi Kuusiku filiaali teaduslik töötaja L. Kōrgas. 
Et Kuusiku katsemajandis oli põldheina keskmine saak 1946. - 50. a. 28,5 ts/ha, siis ületasid kōigi lutsernisortide saagid (seejuures tuleb siiski arvestada, et tegemist oli väiksemate katsepindadega) pō!dheina keskmise saagi ligikaudu kahekordselt, vaatamata sellele, et pöldhein kasvas enamasti sügavamatel ja viljakamatel muldadel. Tuleb märkida sirplutserni - Dedinovi kolla s e - küllalt kõrget saaki, sest katseperioodi kestel saadi selle hektarilt keskmiselt 50,5 ts kuivheina.

Tabel 2

Lutserni kuivheina saagid sōltuvalt sordist ja päritolust ENSV TA Taimekasvatuse Instituudi Kuusiku katsemajandis 1946.-1950, a.

\begin{tabular}{|c|c|c|c|c|c|c|c|c|c|}
\hline \multirow{2}{*}{ Sort } & \multicolumn{5}{|c|}{ Keskmine saak ts/ha } & \multicolumn{2}{|c|}{$\begin{array}{l}\text { Keskmine saak ha-lt aas- } \\
\text { tas } 5 \text { aasta keskmisena }\end{array}$} & \multicolumn{2}{|c|}{$\begin{array}{l}\text { Keskmine } \\
\text { saak ts/ha }\end{array}$} \\
\hline & 1946 & $1947^{-}$ & 1948 & 1949 & 1950 & ts & $\%$ & $\begin{array}{c}2-3 \\
\text { elu- } \\
\text { aastal }\end{array}$ & $\begin{array}{c}5-6 \\
\text { elu- } \\
\text { aastal }\end{array}$ \\
\hline $\begin{array}{l}\text { Balti } 29 \\
\text { Grimm- }\end{array}$ & 23,6 & 59,3 & 60,2 & 89,5 & 85,1 & 63,5 & 100,0 & 41,5 & 87,3 \\
\hline- Zaikevitš & 23,9 & 47,9 & 48,1 & 64,0 & 61,7 & 49,1 & 77,3 & 35,9 & 62,9 \\
\hline Moskva nr. 1 & 24,9 & 53,9 & 56,2 & 75,0 & 73,3 & 56,7 & 89,3 & 39,4 & 74,2 \\
\hline $\begin{array}{l}\text { Ukraina } \\
\text { Dedinovi }\end{array}$ & 21,2 & 49,2 & 41,1 & 64,3 & 57,7 & 46,7 & 73,5 & 35,2 & 60,1 \\
\hline kollane & 27,2 & 56,9 & 43,4 & 80,3 & $*$ & 50,5 & 79,5 & 39,1 & 80,3 \\
\hline
\end{tabular}

Sirplutsernidel on ōhukeste rähkmuldade viljakuse tōstmisel oluline tähtsus, sest nendega rajatud pōlde saab kasutada nii niiteliselt kui ka karjatamiseks. Sinise lutserni ja sinise värdlutserni pōllud olemasolevatel andmetel karjatamist hästi ei kannata. Taimekasvatuse Instituudi KarjaPärsamaa katsemajandis, Orissaare rajoonis, rajati ōhukesel rähkmullal $\left(A_{1}\right.$ 0-10 cm) kohaliku päritoluga sirplutserni - S a a rema a kol. la se lutserni - kasvatamise katse 3-hektarisele alale. Eelviljaks oli kartul, mille väetamiseks oli kasutatud mineraalväetisi. Külv teostati odra alla külvinormiga $15 \mathrm{~kg} \mathrm{~S}$ a a rema a kollast lutserni ja $8 \mathrm{~kg}$ kõrget raiheina hektarile. Külviaastal tärkasid ja arenesid lutsernitaimed puudulikult, eriti katseala sellel osal, mida edaspidi kavatseti kasutada karjatamiseks. Lutsernitaimede tihedus oli siin külviaastal eriti väike. Osa lutsernitaimi tärkas alles järgmisel aastal. Teisel eluaastal (1950) kasutati kogu katsepindala niiteliselt, kusjuures saadi keskmiselt ainult 15 ts kuivheina hektarilt. 1951/52. aastal sai katsepind hektari kohta 3 ts superfosfaati ja 2 ts kaalisoola. 1951, aastaks oli taimede tihedus tunduvalt suurenenud. Samal aastal eraldati osa katsepinnast (2 ha) karjatamiseks. Karjatamiseks eraldatud pinnal oli lutsernitaimede tihedus tunduvalt väiksem kui niiteliseks kasutamiseks jäänud alal. Vaatamata sademetevaesele suvele (sademeid aprillist kuni oktoobrini $201,9 \mathrm{~mm}$, sellest mais-juunis $26 \mathrm{~mm}$ ), saadi karjatatavalt pinnalt ligikaudu 80 ts haljasmassi ha-lt. Taimede tihedus suurenes vegetatsiooniperioodi löpuks. 1952. aastal saadi karjatatavalt pindalalt 116 ts haljasmassi hektarilt (1980 söötühikut). Kokku teostati neli karjatamist, kusjuures esimesel karjatamisel (3. juunil) saadi $39,3 \%$ kogutoodangust, teisel (4. juulil) $-34 \%$, kolmandal (3. augustil) - $18,2 \%$ ja neljandal (oktoobris) - $8,5 \%$. Karjatamise tagajärjel taimkate ei hõrenenud, vaid vastupidi - tihenes. Oktoobris 1952. a. teostatud kamara analüüsi andmetel esines karjatatava ala ruut-

- Kogu katsepind jäetud seemneks. 
meetril keskmiselt 162 , niiteliselt kasutataval alal aga vastavalt 182 lutsernitaime. Kui karjatatava ala taimkate oli esimestel eluaastatel tunduvalt höredam niiteliselt kasutatava ala omast, siis ne:jandal e.uaastal o:i taimkate enam-vähem ühtlustunud. Kōrge raihein esimestel karjatamisaastatel ei hõrenenud. Niiteliselt kasutatava ala saak oli 1952. a. 152 ts haljasmassi hektarilt (vastab 38 ts kuivheinale).

Märkimisväärseid tulemusi on sirplutsernide kasvatamise alal ōhukestel rähkmuldadel saavutatud ka Taimekasvatuse Instituudi Kuusiku katsemajandis. 1950. aastal rajati siin lutserni kasvatamise katse rähkmul:ale, mis kuulub primitiivsete muldade hulka. Rähaga segatud huumuskihi tüsedus on alla $10 \mathrm{~cm}$, millele järgneb munakaline kruus. Sellist maad on peaaegu vōimatu künda. Katsealaks valitud maa oli pikemat aega kasutamata seisnud. Katsepinnale külvati varakevadel 3 ts superfosfaati ja 2 ts kaalisoola hektari kohta. Osa katsealast sai lisaks 10 t sõnniku-turba komposti hektarile. Seejärel teostati pealtharimine labidasäkke (sampo) kolme töökäiguga ja purustatud pind äestati raskete äketega. Külv teostati 8. aprillil, külvinormiga $15 \mathrm{~kg}$ Saaremaa kollast lutserni ja $5 \mathrm{~kg}$ timutit hektarile. Külvi järel katsepind äestati ja rulliti rōngasrulliga. Taimede areng toimus aeglaselt ja külviaasta sügisel teostati ainult hooldamisniit. 1951. aastal saadi katsepinnalt keskmiselt 10 ts kuivheina hektarilt. Vegetatsiooniperioodi lõpuks oli taimede tihedus vaatamata sademetevaesele suve'e suurenenud. 1952. a. kevadel sai katsepõld lisaks fosfor- ja kaaliumväetisele 1,0 ts boor-magneesiumi hektarile. Kuivheina saak fosfor- ja kaaliumväetise väetusvariandilt oli 32,7 ts, fosfor- ja kaaliumväetisega ning kompostiga väetatud variandilt oli 34,7 ts hektarilt. Sellist-saaki maa!t, mis senini praktiliselt midagi ei kasvatanud, tuleb lugeda väga heaks. Katsetulemused näitavad, et lutsernidega on võimalik saada rahuldavaid saake isegi niisugustelt ōhukestelt rähkmuldadelt, millel teised põllukultuurid üldse saaki ei anna.

Senistest katsetulemustest selgub, et $\mathrm{S}$ a a rem a a koll a ne lutsern ei jää saagikuselt maha Dedinovi koll a sest. Ohukese'e rähkmullale rajatud vōrdluskatses Kuusiku katsemajandis andis $\mathrm{S}$ a a rema a koll a ne lutsern 53,8 ts kuivheina hektarilt, Ded i novi koll a ne aga 51,8 ts. Kuigi Saaremaa kollane lutsern oma esimestel eluaastatel on aeglase arenemisega, osutub ta väga vastupidavaks ilmastikutingimustele, kannatab hästi karjatamist ja annab pikema aja kestel rahuldavaid saake isegi ôhematel rähkmuldadel. Nii näiteks on Orissaare rajoonis Vesse kolhoosis rohkem kui 10 aasta vanuseid sirplutsernipõ!de, millel taimede tihe. dus on väga hea, kuigi neil on pidevalt karjatatud isegi lambaid.

\section{Lutserni kasvatamise agrotehnikast}

Taimekasvatuse Instituudi poolt teostatud uurimised aitavad selgitada lutserni külviaegade, külviviiside, niiteaegade ja niitesageduse ning väetamise ja hooldamise küsimusi.

Rea aastate jooksul tehtud tähelepanekute kohaselt on ōhukestel rähkmuldadel osutunud parimaks varakevadine külv kattevilja alla. Sobivaimaks katteviljaks neis tingimustes on oder. Katteviljata külvi puhul on esimestel kasutusaastatel saadud küll veidi kōrgemat saaki, kuid arvestades kogusaake tervel kasutusperioodil, on kattevilja alla külvatud lutserni kogusaak koos kattevilja saagiga võrdne katteviljata külvi saagile. Nii kujunes Kuusiku katsemajandis 5 kasutusaasta puhul külvil kattevilja alla taimesaaduste kogutoodang (lutserni kogusaak + kattevilja saak) katteviljata külvil saadud kogutoodangust isegi 1,2\% võrra kôrrgemaks. Pealegi on külvil kattevilja alla umbrohtumise oht väiksem. Sademete poolest 
normaalsetel suvedel on saadud rahuldavaid tulemusi ka suviste katteviljata külvide puhul, kusjuures külve võib teostada kuni juulikuu viimase dekaadini. Hilisemad külvid on toonud kaasa suure saagilanguse või külvi täieliku ebaônnestumise.

Külviviiside mōju aitavad selgitada tabelites 3 ja 4 toodud andmed.

Tabel 3

Lutserni saagid erinevate külviviiside kasutamisel ENSV TA Taimekasvatuse Instituudi Kuusiku katsemajandis

\begin{tabular}{|c|c|c|c|c|c|c|}
\hline \multirow{2}{*}{$\begin{array}{l}\text { Külviviis ja külvinorm } \\
\text { ha-le }\end{array}$} & \multicolumn{4}{|c|}{ Keskmine saak ts/ha } & \multicolumn{2}{|c|}{$\begin{array}{c}\text { Keskmine saak } \\
\text { ha-lt aastas } 4 \text { aasta } \\
\text { keskmisena }\end{array}$} \\
\hline & 1946 & 1947 & 1948 & 1949 & ts & $\%$ \\
\hline Laialtkülv, $25 \mathrm{~kg}$ & 58,5 & 36,0 & 72,8 & 79,6 & 61,8 & 100,0 \\
\hline Reaskülv, $25 \mathrm{~kg}$ & 58,6 & 35,5 & 69.2 & 84,6 & 62,0 & 100,3 \\
\hline Viirgkülv, $16 \mathrm{~kg}$ & 44,5 & 29,7 & 52,7 & 61,5 & 47,1 & 76,2 \\
\hline Laiarealine kūlv $16 \mathrm{~kg}$ & 34,6 & 31,7 & 46,7 & 63,2 & 44,0 & 71,2 \\
\hline
\end{tabular}

Tabel 4

Lutserni saagid puhaskülvis ja segus kōrrelistega ENSV TA Taimekasvatuse Instituudi Kuusiku katsemajandis 1946-1949. a.

\begin{tabular}{|c|c|c|c|c|c|c|c|c|c|}
\hline \multirow{3}{*}{$\mathrm{K}$ a I $\mathrm{v}$} & \multicolumn{4}{|c|}{$\begin{array}{c}\text { Kuivheina keskmine saak } \\
\text { ha-1t aastas } 4 \text { aasta } \\
\text { keskmisena }\end{array}$} & \multicolumn{2}{|c|}{$\begin{array}{c}\text { Toorproteiini } \\
\text { keskmine } \\
\text { saak ha-It } \\
\text { aastas } \\
\end{array}$} & \multicolumn{3}{|c|}{$\begin{array}{c}\text { Heina keskmine } \\
\text { botaaniline koos- } \\
\text { seis } \%\end{array}$} \\
\hline & \multirow{2}{*}{ 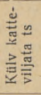 } & \multirow{2}{*}{ 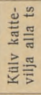 } & \multicolumn{2}{|c|}{$\begin{array}{c}\text { Katse } \\
\text { keskmine }\end{array}$} & \multirow{2}{*}{ ts } & \multirow{2}{*}{$\%$} & \multirow{2}{*}{ 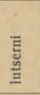 } & \multirow{2}{*}{ 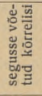 } & \multirow{2}{*}{ 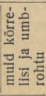 } \\
\hline & & & ts & $\%$ & & & & & \\
\hline \multirow{7}{*}{$\begin{array}{l}\text { Lutsern } 100 \% \\
\text { Lutsern } 70 \%+\text { timut } 30 \% \\
\text { Lutsern } 70 \%+\text { kerahein } \\
30 \% \\
\text { Lutsern } 70 \%+\text { ohtetuluste } \\
30 \% \\
\text { Lutsern } 70 \%+\text { hilisnurmik } \\
30 \% \\
\text { Lutsern } 70 \%+\text { părisaru- } \\
\text { hein } 30 \% \\
\text { Lutsern } 70 \% \text { + kőrge rai- } \\
\text { hein } 30 \%\end{array}$} & 46,6 & 39,6 & 43,1 & 100,0 & 5,05 & 100,0 & 77,0 & $\overline{7}$ & 23,0 \\
\hline & 48,5 & 44,2 & 46,4 & 107,7 & 4,57 & 90,5 & 51, & 37,6 & 10,9 \\
\hline & 39,7 & 35,7 & 37,7 & 87,5 & 3,31 & 65,5 & 48,9 & 46,9 & 4,2 \\
\hline & 45,0 & 42,1 & 43,6 & 101,2 & 3,59 & 71,1 & 43,2 & 46,6 & 10,2 \\
\hline & 49,3 & 47,5 & 48,4 & 112,3 & 4,36 & 86,3 & 53,8 & 33,5 & 12,7 \\
\hline & 43,2 & 41,1 & 42,2 & 97,9 & 3,67 & 72,7 & 53,9 & 37,0 & 9,1 \\
\hline & 47,0 & 45,3 & 46,2 & 107,2 & 4,42 & 87,5 & 55,7 & 37,9 & 6,4 \\
\hline
\end{tabular}

Mã rkus. Tabelis on antud \% liigi puhaskülvi normist ha-le. Katses oli võetud puhaskülvi normiks: lutsern $25 \mathrm{~kg}$, timut $12 \mathrm{~kg}$, kerahein ja kõrge raihein $18 \mathrm{~kg}$. ohtetu luste ja pärisaruhein $32 \mathrm{~kg}$, hilisnurmik $8 \mathrm{~kg}$.

Toodud andmetest selgub, et saak on kõrgeim laialtkülvi ja reaskülvi puhul. Laiarealise külvi puhul vähenes saak ligikaudu $30 \%$ vōrra. Et reaskülvi ja laialtkülvi vahel ei ole märkimisväärset vahet, siis on öhukestel rähkmuldadel sageli otstarbekohasem kasutada laialtkülvi; sest räha rohke esinemise korral on reaskülvi teostamisega raskusi. Tähelepanekud nii katse- kui ka tootmiskogemustest näitavad, et rähkmuldadel on laialt- 
külvi vōi reaskülvi puhul sobivaimaks külvinormiks $20 \mathrm{~kg} / \mathrm{ha}$. Väiksema külvinormi kasutamisel jääb saak esimestel aastatel sageli madalaks. Laiarealise külvi puhul saadakse häid tulemusi tihti isegi külvinormide puhul 6-8 kg/ha. Parema niiskusrežiimiga karbonaatsetel muldadel saab kasutada väiksemaid külvinorme.

Nagu tabelis 4 toodud andmetest selgub, suureneb saak lutserni ja kôrreliste segude kasvatamisel kuni $12 \%$. Kōrrelistest heintaimedest on segudes sobivaimad timut, kõrge raihein ja hilisnurmik. Vähesobivateks osutuvad kerahein ja aruhein, kusjuures eriti tugevasti langeb saak keraheina puhul. Sama selgub ka sirplutserni ja kõrreliste segude kasutamisel. Kuusiku katsemajandis saadi 1952. aastal sirplutserni puhaskülvil hektarilt kuivheina 48,5 ts, sirplutserni ja kōrge raiheina segu puhul 57,0 ts, sirplutserni ja timuti segu puhul 56,0 ts ning sirplutserni ja keraheina segu puhul 45,5 ts. Parimaks komponendiks lutserni ja kôrreliste segudes osutub kõrge raihein, sest viimase kasvutsükkel langeb lutserni omaga hästi ühte. Teiste liiduvabariikide kogemused kinnitavad sama $\left({ }^{6}\right)$.

Kuigi lutserni ja kõrreliste segude kasutamisel suureneb söötühikute toodang, ei kaasne sellega proteiini toodangu suurenemine. Vastupidi lutserni ja kōrreliste segude kasutamisel proteiini toodang langeb. Vaatamata sellele on otstarbekohasem kasvatada lutserni segus kōrrelistega, sest sellega soodustame mullastruktuuri kujunemist. Sellega saame ühtlasi vältida lamandumist ja kergendada heina kuivatamist. Eriti oluline on see sirplutsernide kasvatamisel. Segudesse on seniste kogemuste kohaselt soovitav võtta $70-80 \%$ lutserni ja $20-30 \%$ vastava kõrrelise seemet puhaskülvi normist.

Niitesageduse kohta märgitakse sageli, nagu vốimaldaks lutsern Eesti NSV oludes teostada vegetatsiooniperioodi kestel neli ja isegi rohkem niitu. Siin on tegemist lõunapoolsete kasvatusrajoonide kogemuste kontrollimata üldistusega. Niiteaegade ja niitesageduse mõju lutserni saagi kujunemisele aitavad selgitada Taimekasvatuse Instituudi Kuusiku filiaali poolt teostatud katsed. Katseandmetest selgub, et kōrgema saagi annab lutsern Eesti NSV oludes juhul, kui esimene niitmine teostatakse ajavahemikus ôisikute ilmumisest kuni öitsemise alguseni. Sellisel korral on vegetatsiooniperioodi kestel võimalik teostada kuni 3 niitu. Nelja- ja rohkemkordse niidu puhul tuleb esimene niitmine teostada maikuus. Sellise kasutusviisi puhul väheneb kogusaak nii söötühikutes kui ka proteiini osas $60-80 \%$ vörra öitsemise eelse esimese niitmisega võrreldes. Esimese niidu hilinemisel tõuseb küll heina kogusaak, kuid langeb tunduvalt proteiini saak (tabel 5).

Samasugune vahekord saagi osas esines erinevate niiteviiside kasutamisel sügavamatel muldadel. Paide rajoonis endises Taimekasvatuse Instituudi Huuksi katsepunktis saadi sügavatel, nōrgalt leostunud karbonaatsetel muldadel $4-5$-kordse niidu puhul 65,1 ts lutserniheina hektarilt, kui esimene niitmine teostati aga öitsemise eel (kokku 3 niitu), oli saak 103,1 ts hektarilt.

Kōrgete lutsernisaakide kindlustamiseks vajavad lutsernipōllud pidevalt väetamist fosfor- ja kaaliumväetistega. Eeltoodud katsetes on aastas keskmiselt kasutatud $2-3$ ts superfosfaati ja $1-2$ ts kaalisoola ha-le. Väetamist teostati tavaliselt varakevadel vōi sügisel. Vanematel lutsernipōldudel on saadud häid tulemusi pinnase kevadise kobestamise ja samaaegse väetiste andmise teel. Kuusiku katsemajandis rajati vastav katse 1952. aastal neljanda kasutusaasta lutsernipõldudele. Kogu katsepind sai ühtlase PK väetise, osa katsepōllust aga kultiveeriti piikultivaatoriga keskmiselt $4 \mathrm{~cm}$ sügavuselt. Kobestatud pinnalt oli sinise lutserni kuivheina saak kahest löikusest 104,9 ts/ha, kobestamatult pinnalt aga 86,9 ts/ha. 


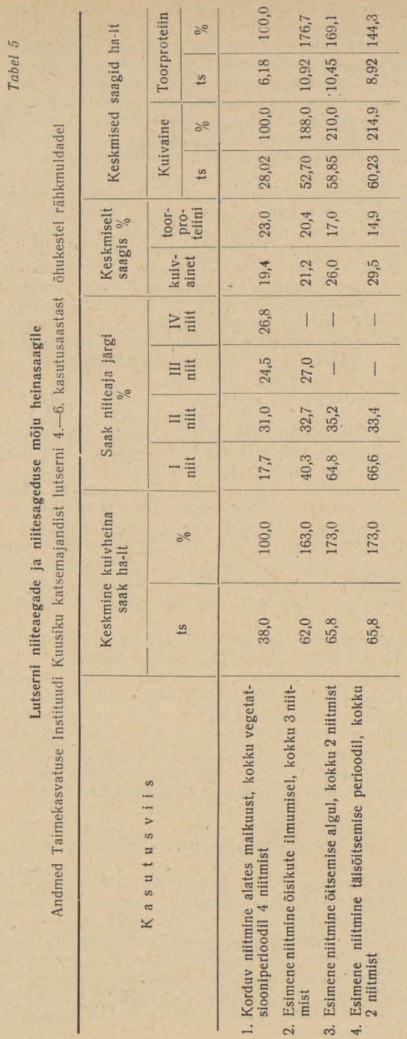


Märkimisväärseid tulemusi on saadud boorväetiste kasutamisel, kusjuures saak on tōusnud keskmiselt $10-12 \%$ pirides. Nii saadi Kuusiku katsemajandis booriga väetatud aladel (väetatud booraksiga $\mathrm{Na}_{2} \mathrm{~B}_{4} \mathrm{O}_{7}$ $5 \mathrm{~kg}$ ha-le) nelja aasta keskmisena 56,3 ts kuivheina hektarilt, väetamata aladelt aga 50,8 ts/ha. Boorväetise môjul suurenes väiksemal määral ka kuivaine protsent. Nii näiteks oli 1947, aastal booriga väetatud lutsernis kuivainet $33,6 \%$, väetamata lutsernis aga $31,8 \%$. Viimastel aastatel on boorväetisena kasutatud peamiselt boormagneesiumi, andes seda hektarile $0,6-1,0$ ts. Boorväetise mõju on pikemaajaline, nagu seda näitavad katseandmed.

Lutserni külvamisel maadele, kus varem lutserni ei ole kasvatatud, on oluline tähtsus seemne inokuleerimisel vastava lutserni mügarbakteritega. Nii saadi Taimekasvatuse Instituudi endises Karuse katsepunktis (Viljandi rajoon) inokuleeritud seemnega külvatud lutsernipōllult 1949. aastal 80,0 ts kuivheina hektarilt, inokuleerimata seemnega külvatud põllult aga ainult 35,7 tsentnerit. Inokuleerimise tulemusena oli saak rohkem kui 2 korda suurem. Veelgi teravamalt avalddus inokuleerimise mõju 1952. aastal Paide rajoonis J. V. Stalini nimelises kolhoosis ja Elva rajoonis Erumäe kolhoosis. J. V. Stalini nimelises kolhoosis oli lutsern külvatud leostunud karbonaatmullale $(\mathrm{pH}$ 6,94). Taimed tärkasid ühtlaselt ja hästi. Juuli lõpul oli ruutmeetril keskmiselt 560-600 lutsernitaime. Enamus taimedest aga olid kidurad ja koltunud, taime keskmine pikkus oli $4-5 \mathrm{~cm}$. Selle kõrval esines üksikuid taimi, mille pikkus ulatus $20 \mathrm{~cm}$ piiridesse. Taimede värvus oli tumeroheline. Kontrollimisel selgus, et kiduratel taimedel puudusid juuremügarad täislikult, hästiarenenud taimedel aga olid ka mügarad hästi arenenud. 1952. a. oktoobris oli suur osa kiduratest taimedest juba hävinenud. Samasugune pilt esines ka Erumäe kolhoosis Elva rajoonis, kus lutsern oli külvatud neutraalsele mullale, kuid samuti inokuleerimata seemnega. Lutsern oli tärganud ühtlaselt ning augusti algul oli ruutmeetril keskmiselt $600-620$ lutsernitaime. Suurem osa taimedest olid kidurad ja kollase värvusega. Esinesid ainult üksikud normaalsed taimed, mille pikkus ulatus $25-35 \mathrm{~cm}$. Oktoobri lõpuks oli siingi tunduv osa taimedest hävinenud. Samale maale külvatud punane ristik arenes jōuliselt.

Lutserni saagi kujunemisele avaldab olulist môju lutsernikülvide hooldamine külviaastal. Kattevilja puudumisel, samuti aga ka kattevilja varasema koristamise puhul niidetakse lutserni juba esimesel eluaastal, s. o. külviaastal, kuid seda tuleb teostada őigel ajal. Katseandmetest selgub, et lutserni varajane niitmine külviaastal nô̆rgendab noorte taimede talvekindlust ja vähendab esimeste kasutusaastate saaki. Nii vähenes lutserni saak Kuusiku katsemajandis, juhul kui külviaasta lutsern niideti augusti lōpul, sordist olenevalt $46-75 \%$. Septembri lōpul või oktoobri algul teostatud niitmine järgmise aasta saagile märkimisväärset mõju ei avaldanud.

\section{Lutserni seemnekasvatusest}

Seemnekasvatus on lutserni kasvatamise laiendamisel üheks teravamaks küsimuseks. Uurimistöö lutserni seemnekasvatuse alal on seni olnud vähe. viljakas. Vähene edu sellel alal on ühelt poolt tingitud sellest; ef küsimuse lahendamiseks rakendatavate agrotehniliste võtete valikul ei ole küllaldaselt arvestatud lutserni bioloogilisi omadusi, teiselt poolt aga sellest. et tööl on puudunud vajalik side tootmispraktikaga.

Senistest uurimistulemustest, eriti aga tootmiskogemustest järeldub, et Eesti NSV oludes on võimalik saada rahuldavaid ja isegi küllalt kōrgeid 
lutserni seemnesaake, kuid peamiseks puuduseks seejuures on saakide juhuslikkus. Hästi iseloomustavad seda lutserni seemnesaagid Taimekasvatuse Instituudi Kuusiku katsemajandis aastatel 1947-1950. Katseandmeist selgub, et Kuusikul on lutserni seemnesaagid aastate järgi väga kõikuvad. Seda kõikuvust on esialgu raske seostada ilmastikutingimustega. Nii oli 1947. a. maikuus sademeid $5,6 \mathrm{~mm}$ (20 a. keskmine 46,3 ), augustis $36,5 \mathrm{~mm}$ (20 a. keskmine $97,6 \mathrm{~mm}$ ), vastavate kuude $t^{\circ}$ olid lähedased 20 a. keskmistele - mais $10,4^{\circ}-10,3^{\circ}$, augustis $16,1^{\circ}-16,0^{\circ} ; 1948$. a. oli mais sademeid $48,4 \mathrm{~mm}$, augustis $157,5 \mathrm{~mm}$, $\mathrm{t}^{\circ}$ olid lähedased 20 a. keskmistele. Juuni- ja juulikuu olid sademete poolest lähedased 20 a. keskmistele. Mõlemal aastal saadi kõigilt katsealustelt sortidelt rahuldavad seemnesaagid. 1949. a. ilmastik oli sademete ja $t^{\circ}$ osas lähedane 1948. aastale, kuid seemnesaak osutus üldiselt madalamaks (tabel 6).

Tabel 6

Lutserni seemnesaagid ōhukestel ja keskmise sügavusega rähkmuldadel ENSV TA Taimekasvatuse Instituudi Kuusiku katsemajandils

\begin{tabular}{|c|c|c|c|c|c|c|c|c|}
\hline \multirow[b]{3}{*}{$\begin{array}{l}\text { Sort/algseemne } \\
\text { paritolu }\end{array}$} & \multicolumn{8}{|c|}{ Seemnesaagid hektarilt kilogrammides } \\
\hline & \multicolumn{2}{|c|}{ 1947. a. } & \multicolumn{2}{|c|}{ 1948. a. } & \multicolumn{2}{|c|}{ 1949. a. } & \multicolumn{2}{|c|}{ 1950. a. } \\
\hline & 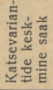 & 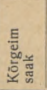 & 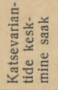 & 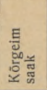 & 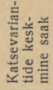 & 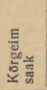 & 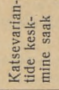 & 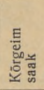 \\
\hline Balti $29-$ & & & & & & & & \\
\hline $\begin{array}{l}\text { Moskva oblast } \\
\text { Grimm-Zaikevits, }\end{array}$ & 163,0 & 318,9 & 134,8 & 134,8 & 33,4 & 37,7 & 49,7 & 87,0 \\
\hline $\begin{array}{l}\text { Moskva oblast } \\
\text { Moskva nr. } 1 \text { - }\end{array}$ & 55,7 & 130,5 & 76,6 & 90,9 & 12,2 & 17,1 & 14,4 & 14,4 \\
\hline Moskva oblast & 123,5 & 206,1 & 110,0 & 149,1 & 14,8 & 14,8 & 24,4 & 24,4 \\
\hline $\begin{array}{l}\text { Ukraina } \overline{N S S} \\
\text { Ukraina }\end{array}$ & 83,5 & 146,5 & 156,4 & 292,8 & - & - & - & - \\
\hline $\begin{array}{l}\text { Dedinovi kollane - } \\
\text { Moskva oblast } \\
\text { Jõgeva - Jõgeva }\end{array}$ & 161,6 & 324,5 & 576,4 & 681,6 & 127,8 & 132,5 & 144,4 & 144,7 \\
\hline $\begin{array}{l}\text { rajoon, Tartu oblast } \\
\text { Balti } 29-\end{array}$ & - & - & - & - & 65,6 & 65,6 & 115,6 & 175,5 \\
\hline kohalik paljundus & - & - & 114,9 & 114,9 & 56,7 & 117,1 & 36,5 & 48,5 \\
\hline
\end{tabular}

Küsimuse lähem analüüs näitab siiski, et lutserni seemnesaak on suurel määral seotud kevadiste niiskusetingimustega. 1947. a. kevadal oli sademeid vähe (aprillist - juunini $60,3 \mathrm{~mm}$ ) ja ôhukestel rähkmuldadel ei piisanud niiskusest õisikute väljakujundamiseks; sügaval karbonaatsel mullal aga jätkus niiskusest ja seemnesaak oli siin 4-6 korda kōrgem kui ōhukesel karbonaatsel mullal. 1949. aastal aga oli sademeid kevadel rohkem (aprillist - juunini $136,2 \mathrm{~mm}$ ) ja seemnesaagid nii õhukesel kui ka sügaval karbonaatsel mullal olid vôrdsed (tabel 7).

Kevad-suvise niiskuserežiimi môju lutserni seemnesaagile ilmnes ka 1952. aastal. Kuusiku katsemajandis kannatasid lutsernitaimed juunis lühikest aega niiskusepuuduse all, kusjuures eriti teravalt avaldus see õhukestel rähkmuldadel. Vaatamata hilisematele sademetele ja lutserni üldiselt kôrgele saagile ei moodustanud lutsern ōhukesel rähkmullal üldse kaunu. Samal ajal aga esines seemnekaunu keskmisest sügavamal karbonaatsel mullal kasvaval lutsernil. 
Boorväetise kasutamisel tôusis Kuusiku katsemajandis 1947.-48. a. teostatud katsetes lutserni seemnesaak $20 \%$ piirides. Nii saadi booriga väetatud katsepôllult kahe aasta keskmisena ha-It 93,7 kg lutserniseemet, väetamata põllult aga $76,3 \mathrm{~kg}$. Boorväetise mõjul suurenes lutserni seemnesaak ka Orissaare rajoonis kolhoosis „Ohendus” teostatud väetuskatsetes (1).

Kuusiku katsemajandis teostatud lutserni seemnekasvatuse katsetest ilmneb, et karbonaatsetel muldadel andsid kōik katsetusel olnud sordid kõrgema seemnesaagi 2. ja 3. eluaastal. Katsetusel olnud sinise lutserni sortidest ei saa ühtegi esile tõsta suurema ja püsivama seemnesaagi poolest. Küll aga andis pidevalt kōrgema seemnesaagi sirplutsern - Dedinovi kollane.

Märkimisväärseid tulemusi on lutserni seemnekasvatuse alal saavutatud

Tabel 7

Lutserni seemnesaagid $\mathrm{kg} / \mathrm{ha}$ sōltuvalt mullastikust ja kevadperioodi sademetest ENSV TA Taimekasvatuse Instituudi Kuusiku katsemajandis

\begin{tabular}{l|c|r|c|c}
\hline \multirow{2}{*}{ S o r t } & \multicolumn{2}{|c|}{ Ohukesel karbonatsel mullal } & \multicolumn{2}{c}{ Sügaval karbonaatsel mullal } \\
\cline { 2 - 3 } & 1947. a. & 1949. a. & 1947. a. & 1949. a. \\
\hline Balti 29 & 63,7 & 12,7 & 262,4 & 13,9 \\
Moskva nr. 1 & 34,0 & 14,8 & 188,0 & 14,8 \\
Dedinovi kollane & 35,7 & 128,7 & 287,6 & 124,9 \\
\hline
\end{tabular}

Orissaare rajooni kolhoosides. 1950. aastal saadi Viktor Kingissepa nimelises kolhoosis hektarilt $323 \mathrm{~kg}$ seemet. Seemnepōld oli rajatud laiarealises külvis, kevadel väetati seemnepõlde PK väetisega, õitsemise ajal teostati korduvalt kunstlikku tolmutamist. 1951. aastal saadi sama rajooni kolhoosis „Randlane" 4-hektariselt lutserni seemnepôllult $130 \mathrm{~kg}$ seemet ha-lt, kolhoosis „Kaljukotkas” aga 2-hektariselt pôllult $173 \mathrm{~kg}$ seemet ha-1t. Orissaare rajoonis said kolhoosid 1951. aastal üle 30 ts lutserniseemet.

Eriti märkimisväärseid tulemusi saavutati lutserni seemnekasvatuse alal Orissaare rajoonis Saarte lastekodu abimajandis. Seemnepōld rajati 1949. aastal keskmise sügavusega karbonaatsele mullale laiarealises külvis (reavahe $60 \mathrm{~cm}$ ), külvinormiga $8 \mathrm{~kg}$ ha-le. Seeme oli sinise lutserni kohalik hübriidvorm. Seemnepôllule anti nii rajamisel kui ka järgmistel aastatel 3,0 ts superfosfaati ja 2 ts kaalisoola ha kohta. Lisaks sellele anti rajamise aastal ja sellele järgneval aastal ha-le 0,5 ts ammoonsalpeetrit. Reavahed hariti sügavalt, nii et lutserni read asusid tegelikult vagude harjadel. Vaheltharimist teostati kuni õitsemise lõpuni (3-4 korda). 1950. aastal saadi seemnepôllult $326 \mathrm{~kg}$ seemet hektarilt, 1951. aastal $456 \mathrm{~kg}$.

Katsetulemustest ja tootmiskogemustest järeldub, et lutserni seemnepôllud tuleks rajada esijoones keskmise sügavusega väherähksetele või sügavatele karbonaatsetele muldadele laiarealises külvis. Kasutades suurendatud fosfor- ja kaaliumväetiste norme, boorväetist, sügavat ridadevahelist harimist ja kunstlikku täiendavat tolmutamist, vơib oodata märkimisväärseid seemnesaake. Seemnekasvatamisel tuleks erilist tähelepanu pöörata niiskuse reguleerimisele sügava vaheltharimisega õisikute moodustumise ja öitsemise perioodil.

Lutserni kasvatamisega seoses olevaid uurimistulemusi ja tootmiskogemusi kokku võttes võib märkida järgmist:

Maaviljeluse heinaväljasüsteemi sisseviimise käigus on lutserni kasvatamise laiendamine karbonaatsetel muldadel esmajärgulise tähtsusega ülesandeks, sest see võimaldab tunduvalt tõsta taimekasvatuse kogutoodangut. 
Eriti oluline tähtsus on lutserni kasvatamise organiseerimisel ōhukestel karbonaatsetel muldadel, sest sellega on vahetult seotud nende muldade viljakuse otsustav tõstmine. Sisuliselt tähendab see kümnete tuhandete hektarite vähetootlike maade muutmist kõrgetoodanguliseks. Lutserni kasvatamisega on vöimalik neil muldadel seniste $600-800$ söötühiku asemel toota hektari kohta keskmiselt 2000-3000 söötühikut, seejuures 10 tsentneri piirides proteiini. Söödabaasi laiendamisel on see olulise tähtsusega.

Lutserni kasvatamist ōhukestel karbonaatsetel muldadel tuleb organiseerida pikemaajalise kestvusega söödakülvikordades, sest lutsern saavutab õhukestel karbonåatsetel muldadel täie saagivõime alles 4. -5. eluaastal, seejärel aga suudab öige agrotehnika rakendamisel anda rahuldavaid saake pikema aja kestel.

Lutserni kasvatamise laiendamisel tuleks esialgu tunduvas ulatuses baseeruda teistest liiduvabariikidest sissetoodavale seemnele. Seoses sellega tuleks karbonaatsete muldade valdkonnas laiendada kôrsheinte seemnekasvatust, et saadud kõrsheinaseemne vastu vahetada lutserniseemet. Kõrsheinte seemnekasvatuse laiendamiseks on siin vajalikud eeldused olemas, sest rohumaade protsent pōllumajanduslike kōlvikute kogumispindalast on siin kõrge ja seetõttu on kerge leida sobivaid maid kõrsheinte seemnekasvatuseks, ilma et sellega seoses oleks vajalik pōllukultuuride kasvupindala vähendada.

Tuleb igati laiendada lutserni seemnekasvatust kohapeal. Kohalikud looduslikud tingimused ei kindlusta küll kasutadaoleva sordimaterjali juures pidevalt rahuldavaid seemnesaake, kuid arvestades seda, et rajatud lutsernipōlde on vōimalik kasutada pikema aja kestel, ei tekita erilisi raskusi lähemas tulevikus täielikult üle minna kohapeal kasvatatud seemnetele. Lutserni seemnepõllud tuleksid rajada esijoones keskmise sügavusega väherähksetele vōi sügavatele karbonaatsetele muldadele, sest siin on vơimalik kergemini reguleerida niiskusetingimusi vastavalt lutserni bioloogilistele nõuetele õisikute ja viljade moodustamise perioodil.

Karjatamiskindlate lutserniväljade rajamiseks ōhukestel rähkmuldadel tuleb pöörata tähelepanu sirplutserni, eriti viimase kohalike vormide seemnekasvatusele.

Lutserni kasvatamise laiendamisel tuleb kindlustada seemne inokuleerimine.

Lutserni karbonaatsetel muldadel kasvatamise küsimuse lahendamine loob vajalikud eeldused lutserni kasvatamise laiendamiseks ka teistel mullatüüpidel, esmajoones farmilähedastel külvikorramaadel.

Teaduslikel uurimisasutistel tuleks esijoones tähelepanu pöörata selliste lutserni seemnete kasvutingimusi reguleerivate abinõude väljatöötamisele, mis soodustaksid ôisikute ja viljade arenemist ja pidurdaksid samaaegselt vegetatiivset kasvu ōitsemisperioodil. Rööbiti sellega tuleks asuda nende agrotehniliste vōtete sełgitamisele, mis aitaksid tôsta vanemate lutsernipōldude saagikust. Oksikud eesrindlikud lutsernikasvatajad on sellel alal saavutanud märkimisväärseid tulemusi, kuid need kogemused on üldistamata.

Lutserni kasvatamise laiendamisel kujunes 1952. aasta murranguliseks. Teistest liiduvabariikidest saadud seemnete arvel suurenes lutserni kasvupindala vabariigis eelmise a astaga vōrreldes rohkem kui kolm korda. Koos sellega laienesid otsustavalt võimalused lutsernikasvatuse edasiseks kiirendatud arendamiseks. Neid vōimalusi ei vōi jätta kasutamata, sest lutserni kasvatamise kiire laiendamine on pōhiliseks lüliks karbonaatsete muldade, eriti aga õhukeste rähkmuldade viljakuse tõstmisel.

Eesti NSV Teaduste Akadeemia

Taimekasvatuse Instituut 
1. A. Abe, Lutserni seemnekasvatuse kogemusi, „Sotsialistlik Pöllumajandus”, 1952, nr. 7 , Ik. $542-543$.

2. Eesti pōllumajandusteadus pōllumajanduse teenistuses. RK .,Teaduslik Kirjandus", Tartu, 1946.

3. А. И. Л и ллем а а, Почвенные районы ЭССР, Сборник Академин наук Эстонской ССР, «О развитни советской науки в Эстонской ССР 1940-1950», Таллнн, 1950, стр. $542-543$.

4. Т. Д. Лысенко, Об агрономическом учении В. Р. Вильямса, «Правдах, 15 июля $1950 \mathrm{r}$.

5. М. И. Н ен ароков, Люцерна желтая. Многолетнне травы в лугопастбищных севооборотах, Сельхозгнз, 1951, стр. 230-240.

6. В. А. Черкасова, Райграс высокнй. Многолетние травы в лугопастбншных севооборотах, Сельхозгиз, 1951, стр. 172-179.

7. А. А. Щ и бря, Лющерна синяя или посевная. Многолетние травы в лугопастбищных севооборотах, Сельхозгиз, 1951, стр. $241-252$.

\title{
КУЛЬТУРА ЛЮЩЕРНЫ В ЭСТОНСКОЙ ССР
}

\author{
Р. И. ТООМРЕ, \\ кандидат сельскохозяйственных наук
}

\section{Peзюоле}

Возделыванием люцерны в Эстонской ССР занимаются в ограниченных размерах уже многие годы. В 1951 году посевная площадь люцерны составляла всего лишь $0,2 \%$ общей площади полевых - трав. Люцерну возделывают в Әстонской ССР пренмущественно на карбонатных почвах.

В связи с введением в колхозах республики травопольных севооборотов остро встал вопрос о расширении посевов люцерны. На маломощных щебенчатых и отчасти также на среднемощных карбонатных почвах посевы смеси клевера с тимофеевкой не удаются по причине частого недостатка влаги в верхнем горизонте почвы. Низкие урожаи по той же причине дают на этих почвах также многие другие полевые культуры. Принимая во внимание, что маломощные карбонатные почвы занимают $8 \%$ территории республики, а в отдельных районах они составляют до $50 \%$ площади пашни, встает неотложный вопрос о том, как повысить продукцию растенневодства на таких почвах. Так как в глубоких слоях щебенчатых карбонатных почв имеются достаточные запасы влаги, то на них следует выращивать главным образом такие культуры, которые способны удовлетворить свою основную потребность в воде за счет более глубоких горизонтов почвы. Такой культурой является, в первую очередь, люцерна, корни которой глубоко проникают в почву.

Вопросами выращивания люцерны. в республике занимаются кафедра растениеводства Эстонской сельскохозяйственной академии, Иыгеваская государственная селекционная станция и Институт растениеводства Академии наук Әстонской ССР. Целью исследовательской работы Института растениеводства является выяснение агротехники возделывания люцерны на карбонатных, в особенности же на маломощных карбонатных почвах.

Результаты многолетних исследований показывают, что посевами люцерны можно резко увеличить продукцию растениеводства на маломощных карбонатных почвах. Так, в опытном хозяйстве Куузнку Института растениеводства в опыте, заложенном с посевами люцерны на маломощных карбонатных почвах, в среднем за 4 года было получено 65,8 ц су- 
хого сена люцерны с 1 га. В первые два года пользования урожай дюцерны был выше урожая смеси клевера с тимофеевкой на $56,2 \%$. Урожай люцерны на маломощных карбонатных почвах в первые годы пользования был значительно ниже, чем в последующие годы. Так, на второй и третий год пользования было получено в среднем 41,5 щ сухого сена люцерны с 1 га, а на пятый и шестой год - 87,3 ц.

В опытном хозяйстве Куузику Института растениеводства в 1952 году на маломощных карбонатных почвах с посевов люцерны в возрасте от 4 до 6 лет за первый укос было получено 50,4 ц сухого сена с 1 ra. Средний урожай люцерны на этих скудных почвах на $16,3 \%$ превышал урожай смеси клевера с тимофеевкой на более мощных н плодородных почвах.

В совхозе имени А. Соммерлинга, Харьюского района, с посевов люцерны на площади 14 га на маломощных и среднемощных карбонатных почвах в среднем за три года пользования по первому укосу было получено 61 д сухого сена с I га. Урожай люцерны в этом колхозе почти в два раза превышал урожай смеси клевера с тимофеевкой.

В колхозах Ориссаареского района в 1951 и 1952 году урожаи люцерны с посевов старше 10 лет составляли 40-70 ц сухого сена с 1 га. Посевы люцерны находятся здесь на маломощных карбонатных почвах, на которых урожайность других полевых культур чрезвычайно низка. При этом необходимо отметить, что урожаи люцерны с посевов 2-го и 3-го года жизни были ниже, чем с посевов старшего возраста.

Из результатов опытов видно, что возделыванием люцерны можно резко увеличить продукцию растениеводства на маломощных карбонатных почвах. На этих почвах люцерна начинает давать более высокие урожаи на 3 -4-й год жизни и затем может обеспечить высокие урожаи в течение $7-8$ лет и более. Исходя из этого, необходимо на таких почвах оставлять люцерну в кормовых севооборотах на длительное время.

Из травосмесей люцерны со злаковыми наиболее пригодными для карбонатных почв оказались смеси люцерны с райграсом высоким и люцерны с тимофеевкой. Средний урожай за четыре года смеси люцерны с райграсов высоким был выше урожая чистых посевов люцерны на $7,2 \%$ и люцерны с тимофеевкой - на $7,7 \%$.

Как показали опыты, люцерну на маломощных карбонатных почвах следует высевать в количестве около 20 кг на 1 га.

В условиях Эстонской ССР на урожаи лющерны большое влияние оказывает срок первого укоса и число укосов. Наиболее высокий урожай сена, а также н протеина получается при проведении первой косьбы в стадии бутонизации до начала цветения. В таком случае на посевах синей люцерны можно провести до трех укосов за лето. Проведение четырех и более укосов снижает урожай люцерны по кормовым единицам н по содержанию протеина в нем на $60-80 \%$. При более позднем сроке первого укоса валовой сбор сена увеличивается, но зато значительно снижается содержание протеина. Так, по данным опытного хозяйства Куузику Института растениеводства, при проведении первого укоса в стадии бутонизации, и при трех укосах за вегетацию в среднем за четыре года было получено с 1 га 62,0 ц сена, с содержанием 10,9 ц протеина, а при четырехкратном укосе - 38,0 ц сена, содержащего протеина 6,2 ц. При проведении же первого укоса в период полного цветения, всего за два укоса было получено сена 65,8 ц, протенна - 8,9 ц.

Урожаи старых посевов люцерны значительно повысились, когда одновременно с внесением фосфорно-калийных удобрений проводилось рыхленне, почвы культиватором. Так, в опытном хозяйстве Куузику с посева люперны четвертого года пользования на маломошной карбонат- 
ной почве, после проведения рыхления и внесения фосфорно-калийных удобрений, было получено 104,9 ц сухого сена с 1 га, а с той части поля, которая осталась без рыхления - 86,9 ц. Внесение бора увеличивало урожай сена люцерны с 1 га в среднем на $10-12 \%$.

В год высева косить люцерну следует только поздней осенью. При проведении косьбы в конце августа урожай люцерны снижается на $46-75 \%$, в зависнмости от сорта. Проведение косьбы в конще сентября и в начале октября не оказывает отрищательного влияния на урожай следующего года. На маломощных карбонатных почвах рекомендуется проводить посев люцерны под покров. В этих условнях хорошим покровным растением является ячмень.

Имеющиеся в республике посевы люцерны заложены семенами, полученными преимущественно из более южных районов. Опытные данные, а также пронзводственная практика показывают, что семена люцерны, полученные из более южных районов, могут быть с успехом использованы для расширения посевов люцерны в Эстонской ССР.

Наряду с посевами синей люцерны и ее гибридов хорошие результаты дали посевы серповидной люцерны. Особенно необходимо отметить дединовскую желтую люцерну и местную серповидную, введенную в культуру на острове Сааремаа. По данным опытов сортоиспытания, посевы синей люцерны семенами, полученными из Московской областн и из Украинской ССР, дали урожай сена в среднем около 50 ц с 1 га; такой же урожай дала дединовская желтая люцерна.

Местная серповидная желтая люцерна с островов является выпасоустойчивой. Она дает удовлетворительные урожаи даже на самых маломощных карбонатных почвах. На опорном пункте Қарья-Пярсама Института растениеводства с люцернового поля, заложенного семенами местной желтой люцерны на почве с горизонтом $A_{1} 0-10$ см (на глинистом хряще), был получен в 1952 году урожай зеленой массы - 116 ц, при этом в течение лета было проведено 4 стравливания. На островах встречаются посевы местной серповидной лющерны, заложенные более 10 лет назад, но имеющие еще густой травостой.

Результаты опытов показывают, что в условиях Эстонской ССР имеется возможность получить удовлетворительные и даже высокие урожаи семян люцерны, но главным недостатком при этом является неустойчивость урожаев. В опытном хозяйстве Куузику Института растениеводства урожаи семян люцерны составляли до 6,8 ц с 1 га. Урожай семян в общем колеблется в пределах от 1,0 до 1,5 ц, а в отдельные годы было получено всего лишь 0,5 ц с 1 га и даже менее. В опытах сорта синей люцерны дали более или менее одинаковые урожаи сортов семян; более устойчивой и продуктивной оказалась балтийская 29. Из серповндной люцерны дединовская желтая дала значительно более высокие урожаи семян по сравнению с сортами синей люцерны. За четыре года средний урожай семян упомянутого сорта был не ниже 1,3 цс 1 га и наиболее высоким урожай - 6,8 ц с 1 га. Во всех опытах урожай семян люцерны 1-го и 2-го года пользования был выше, чем более старших возрастов. При применении борных удобрений урожай семян увеличнвался примерно на $20 \%$.

Удовлетворительные результаты получены по выращиванию семян люцерны также и в производственных условиях. В колхозе имени Кингисеппа, Ориссаареского района, получено в 1950 году с 1 га 3,2 ц семян люцериы. В том же районе в 1951 году получены урожаи семян люцерны: в колхозе «Рандлане» с площади 4,0 га по 1,3 ц с 1 га, в колхозе «Кальюкотка»- 1,7 ц с 1 га. Хорошие результаты по выращиванию люцерны на семена были получены в подсобном хозяйстве детдома 
«Саарте», Ориссаареского района. В этом хозяйстве было получено с 1 га семян люцерны: в 1950 году $-3,3$ ц и в 1951 году $-4,6$ ц. При выращивании семенной люцерны высокие урожаи семян получены при широкорядном посеве (ширнна междурядий $50-60 \mathrm{~cm}$ ) на средних и мощных карбонатных почвах. На повышение урожая семян оказали влияние, наряду с внесением фосфорно-калийных и борных удобрений, глубокая обработка междурядий, проводившаяся 4 раза, с весны и до конца цветения, а также дополнительное опыление.

В итоге необходимо отметить, что расширение посевов люцерны на карбонатных, особенно же на маломощных карбонатных почвах, является первостепенной задачей в деле укреплення кормовой базы. С помощью этого мероприятия имеется возможность увеличить продукщию растениеводства на маломощных карбонатных почвах с 600-800 кормовых единиц с 1 га до 2000-3000 кормовых единиц, т. е. в 3-4 раза.

Для расширения посевов люцерны в первое время придется пользоваться семенами, полученными из южных районов СССР.

Наряду с расширением посевов лющерны следует разрешить вопрос о получении устойчивых урожаев семян. Полученные результаты в этой области показывают, что есть перспективы создания местного семеноводства.

Институт растеншеводства

Академии наук Эстонской ССР 